\title{
Task 2.6 - Catalyst for Utilization of Methane in Selective Catalytic Reduction of NOx
}

\author{
Topical Report \\ July 1, 1995
}

RECENVED

AUG 141997

OSTI

Work Performed Under Contract No.: DE-FC21-93MC30097

For

U.S. Department of Energy

Office of Fossil Energy

Federal Energy Technology Center

Morgantown Site

P.O. Box 880

Morgantown, West Virginia 26507-0880
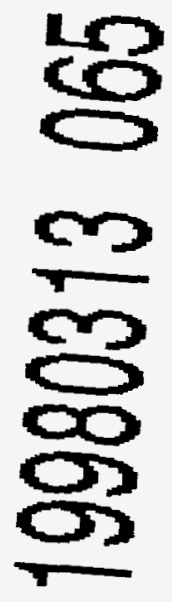

By

Energy \& Environmental Research Center University of North Dakota P. O. Box 9018

Grand Forks, North Dakota 58202-9018

DKTAMBUTON OF THIS DOCUMENT IS URIMITED 


\section{Disclaimer}

This report was prepared as an account of work sponsored by an agency of the United States Government. Neither the United States Government nor any agency thereof, nor any of their employees, makes any warranty, express or implied, or assumes any legal liability or responsibility for the accuracy, completeness, or usefulness of any information, apparatus, product, or process disclosed, or represents that its use would not infringe privately owned rights. Reference herein to any specific commercial product, process, or service by trade name, trademark, manufacturer, or otherwise does not necessarily constitute or imply its endorsement, recommendation, or favoring by the United States Government or any agency thereof. The views and opinions of authors expressed herein do not necessarily state or reflect those of the United States Government or any agency thereof. 


\section{DISCLAIMER}

This report was prepared as an account of work sponsored by an agency of the United States Government. Neither the United States Government, nor any agency thereof, nor any of their employees makes any warranty, express or implied, or assumes any legal liability or responsibility for the accuracy, completeness, or usefulness of any information, apparatus, product, or process disclosed or represents that its use would not infringe privately owned rights. Reference herein to any specific commercial product, process, or service by trade name, trademark, manufacturer, or otherwise does not necessarily constitute or imply its endorsement, recommendation, or favoring by the United States Government or any agency thereof. The views and opinions of authors expressed herein do not necessarily state or reflect those of the United States Government or any agency thereof.

\section{ACKNOWLEDGMENT}

This semiannual was prepared with the support of the U.S. Department of Energy (DOE), Morgantown Energy Technology Center, Cooperative Agreement No. DE-FC21-93MC30097. However, any opinions, findings, conclusions, or recommendations expressed herein are those of the author(s) and do not necessarily reflect the views of the DOE.

\section{EERC DISCLAIMER}

LEGAL NOTICE This research report was prepared by the Energy \& Environmental Research Center (EERC), an agency of the University of North Dakota, as an account of work sponsored by U.S. Department of Energy. Because of the research nature of the work performed, neither the EERC nor any of its employees makes any warranty, express or implied, or assumes any legal liability or responsibility for the accuracy, completeness, or usefulness of any information, apparatus, product, or process disclosed, or represents that its use would not infringe privately owned rights. Reference herein to any specific commercial product, process, or service by trade, trademark, manufacturer, or otherwise does not necessarily constitute or imply its endorsement or recommendation by the EERC. 


\section{TABLE OF CONTENTS}

LIST OF FIGURES $\ldots \ldots \ldots \ldots \ldots \ldots \ldots \ldots \ldots \ldots \ldots \ldots \ldots \ldots \ldots$

EXECUTIVE SUMMARY $\ldots \ldots \ldots \ldots \ldots \ldots \ldots \ldots \ldots \ldots \ldots \ldots$ ii

1.0 INTRODUCTION $\ldots \ldots \ldots \ldots \ldots \ldots \ldots \ldots \ldots \ldots \ldots \ldots \ldots \ldots \ldots$

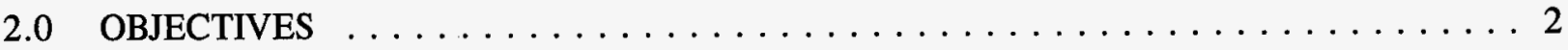

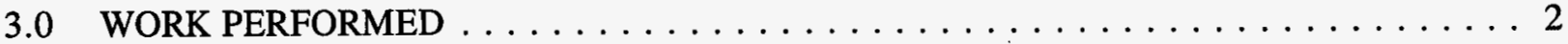

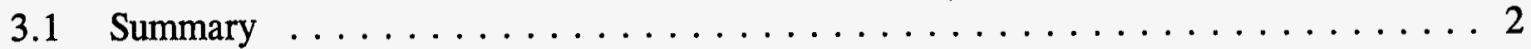

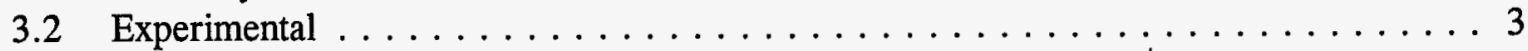

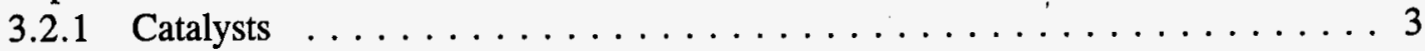

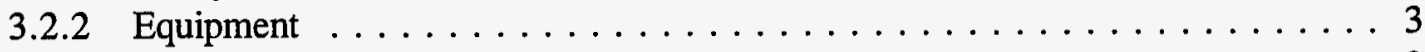

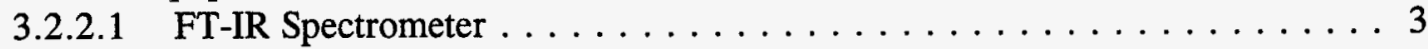

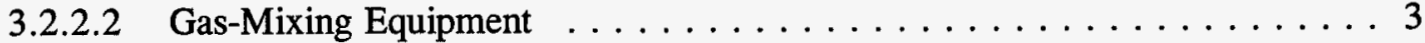

3.2 .3 Procedure . . . . . . . . . . . . . . . . . 4

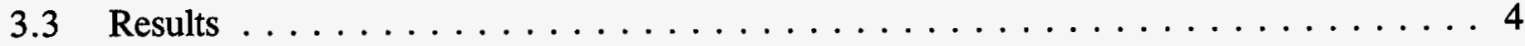

3.3.1 Selective Catalytic No Reduction with Methane in Air $\ldots \ldots \ldots \ldots \ldots . \ldots 4$

3.3.2 Catalytic Reduction of NO with Methane-Derived Intermediates . . . . . . 6

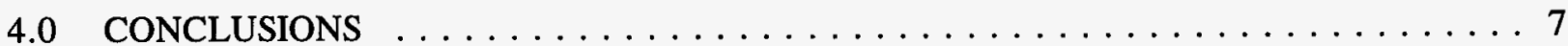

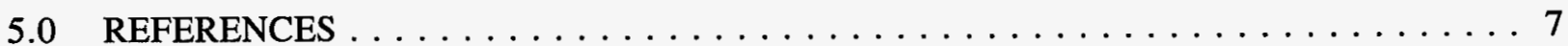

\section{LIST OF FIGURES}

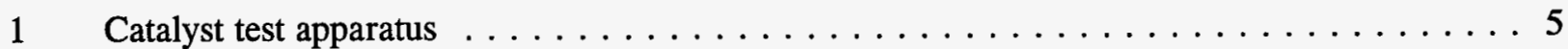




\section{TASK 2.6 - CATALYST FOR UTILIZATION OF METHANE IN SELECTIVE CATALYTIC REDUCTION OF NO}

\section{EXECUTIVE SUMMARY}

Selective catalytic reduction (SCR) of nitrogen oxides $\left(\mathrm{NO}_{\mathrm{x}}\right)$ in flue gas or engine exhaust gas with hydrocarbons as the reductant has great potential for less expense, less pollution, and easier operation than SCR with ammonia. Methane is the preferred reducing gas because of its low cost and low toxicity. Stable, low-cost catalysts for SCR with methane are required to demonstrate this technology for controlling $\mathrm{NO}_{\mathrm{x}}$ emissions. Several cobalt and nickel catalysts on synthetic clay and uranium oxide supports were investigated for their activities in reducing $\mathrm{NO}_{\mathrm{x}}$ with methane in the presence of air.

The efficiency of the synthetic clay-supported nickel and cobalt catalysts for nitric oxide (NO) reduction with methane as the reducing gas was poor. The nickel oxide-uranium oxide catalyst, which was chosen for its high stability, was also ineffective.

Results from the two-step experiments conducted at two temperatures produced some interesting information on the reactions of methane with the catalysts and the reactivity of the carbonaceous intermediate. The carbonaceous material formed from methane dissociation at $450^{\circ} \mathrm{C}$ not only reduces $\mathrm{NO}$ to $\mathrm{N}_{2} \mathrm{O}$ at lower temperatures, but also prevents oxidation of $\mathrm{NO}$ to $\mathrm{NO}_{2}$. Unfortunately, the carbonaceous forms that reduce the $\mathrm{NO}$ are not available for reactions at $400^{\circ} \mathrm{C}$ in the presence of oxygen. A two-step process employing this chemistry would be difficult because the catalyst would have to be cycled between the two temperatures. Also the desired reduction to nitrogen is not very efficient. 


\section{TASK 2.6 - CATALYST FOR UTILIZATION OF METHANE IN SELECTIVE CATALYTIC REDUCTION OF NO}

\subsection{INTRODUCTION}

The combustion of fossil and biomass fuels results in the emission of nitrogen oxides $\left(\mathrm{NO}_{\mathrm{x}}\right)$, which play a damaging role in the environment through smog formation, acidic deposition, depletion of the stratospheric ozone layer, the greenhouse effect, and effects on human health. Nitric oxide (NO) is the main $\mathrm{NO}_{\mathrm{x}}$ component (90\%-95\%) formed in the combustion of fossil fuels and is rapidly converted to $\mathrm{NO}_{2}$ in the atmosphere. Smaller amounts of $\mathrm{N}_{2} \mathrm{O}$ are formed and subsequently converted to NO. The primary nitrogen source can be either air or fuel. Power plants are responsible for $25 \%$ of the human-generated $\mathrm{NO}_{\mathrm{x}}$ and transportation systems for about $50 \%$, with domestic combustion, biomass burning, and agricultural production accounting for smaller amounts (1). $\mathrm{NO}_{\mathrm{x}}$ emissions are increasing at a fast rate, and, consequently, regulations to reduce this emission have been enacted. In order to meet the National Ambient Air Quality Standards (NAAQS) for ozone, urban areas must implement $\mathrm{NO}_{\mathrm{x}}$ control regulations (2).

Several options are available for reducing $\mathrm{NO}_{\mathrm{x}}$ in combustion plants, but each has disadvantages. Various modifications to the combustion systems have achieved moderate $\mathrm{NO}_{x}$ reductions. However, postcombustion $\mathrm{NO}_{\mathrm{x}}$ reduction processes (with a reductant such as ammonia) can give high removal efficiencies, especially those that employ a selective catalyst that gives higher reaction rates with $\mathrm{NO}_{\mathrm{x}}$ than with the oxygen present in the flue gas. In order to be more widely applied in the United States, operating costs for the process must be lowered and, at the same time, nonpolluting reducing gases must be developed to replace the ammonia reductant.

The abatement of $\mathrm{NO}_{\mathrm{x}}$ emissions from coal-fired and other combustion units has employed several methods for postcombustion $\mathrm{NO}_{x}$ reduction, including selective noncatalytic reduction (SNR) with ammonia or urea injections in a high-temperature zone $\left(>800^{\circ} \mathrm{C}\right)$, nonselective catalytic reduction (NCR) with $\mathrm{CO}$ or $\mathrm{H}_{2}$, and selective catalytic reduction (SCR). In SCR, the reducing gas exhibits selectivity favoring the reaction with $\mathrm{NO}_{\mathrm{x}}$ over the reaction with oxygen; therefore, SCR can be used when oxygen is present in the flue gas, which gives SCR a large advantage over NCR. SCR operates at a lower temperature $\left(150^{\circ}-600^{\circ} \mathrm{C}\right)$ than SNR, which means it can be used after an air preheater exchange. In the tail end design, the flue gas is reheated prior to SCR.

Ammonia is used as the reductant gas in several SCR applications in Europe and Japan and can achieve $\mathrm{NO}_{x}$ reductions of greater then $90 \%$ (3). Although ammonia is effective for reducing NO in an oxidizing atmosphere, the excess ammonia required (ammonia slip) can contribute to toxic emissions or can form plugs of ammonium bisulfate. This can cause problems with increased pressure, poor heat exchange, and down time for washing out the ammonium salts.

SCR of $\mathrm{NO}_{\mathrm{x}}$ in flue gas or engine exhaust gas with hydrocarbons as the reductant has great potential for less expense, less pollution, and easier operation than SCR with ammonia. Attention has focused on the use of light gases such as ethylene, propane, and propylene for SCR in flue gas containing oxygen. The excess oxygen in the flue gas results in an enhancement of the catalyst activity for selective $\mathrm{NO}_{\mathrm{x}}$ reduction by the hydrocarbons. 
Several catalysts have been tested for SCR with hydrocarbons in the presence of oxygen. The most effective catalysts are the transition metal-exchanged zeolites $(4,5)$. In a comparison of the activities of a large number of zeolite and other supported metals with ethylene reductant in $2 \%$ oxygen, Sato and others (4) found that Fe-ZSM-5, Fe-silicate, and Fe-mordenite were effective catalysts at the lowest temperatures $\left(200^{\circ}-300^{\circ} \mathrm{C}\right)$. Cu-ZSM-5 was also effective at $250^{\circ} \mathrm{C}(5,6)$, Co-ZSM-5 at $400^{\circ} \mathrm{C}, \mathrm{Ag}-\mathrm{ZSM}-5$ at $500^{\circ} \mathrm{C}$, and Zn-ZSM-5 at $600^{\circ} \mathrm{C}$ (5). The Ce- and Pr-ZSM-5 catalysts were found to be highly reactive for SCR with propylene at $400^{\circ} \mathrm{C}$ (7). Ga-ZSM-5 exhibited very high activity and selectivity with propane as the reductant (8). Fe-silicate showed high activity for SCR with propylene and was not affected much by $\mathrm{SO}_{2}$ (9). The H-form of , zeolites and alumina also exhibits some activity $(10,11)$ at temperatures above $400^{\circ} \mathrm{C}$.

The unsaturated hydrocarbons (propylene and ethylene) are more reactive with NO than the saturated gases. The NO conversions with some catalysts, e.g., the Ga-ZSM-5, were $100 \%$ (8). Isobutane was shown to be quite active, and the zeolite-catalyzed cracking of the isobutane was demonstrated (12). The light hydrocarbon olefins and alkanes are, of course, petroleum refinery products and are widely used chemical feedstocks. Their cost will increase substantially if oil prices rise. The transportation costs from a refinery to the combustion plant site may be a significant factor in their price. The use of low- or negative-cost hydrocarbon sources that are available universally or at least close to the combustion plants would facilitate the development of SCR with hydrocarbon reductant.

Recently methane has been successfully utilized for SCR. Methane is relatively inexpensive and readily available in most localities via pipeline. The selective catalysis of methane reaction with $\mathrm{NO}_{\mathrm{x}}$ is more difficult to achieve, however. Alumina and tin oxide are used at high temperatures, but they are not very selective catalysts. Cobalt-loaded zeolites exhibit the required selectivity for NO $(13,14)$. Since a methane SCR technology has not yet been commercialized, there are still questions concerning the temperatures required, and the stability of the catalyst to the sulfur acids formed in flue gases may be a problem. Thus stable, low-cost, low-temperature catalysts and reducing gas systems need to be investigated for effective $\mathrm{NO}_{\mathrm{x}}$ removal.

\subsection{OBJECTIVES}

The objective of this work was to demonstrate that catalysts consisting of metal ion impregnated on a clay or pillared clay support or on a highly stable composite support are effective for SCR of $\mathrm{NO}_{\mathrm{x}}$.

\subsection{WORK PERFORMED}

\subsection{Summary}

Nickel-substituted mica montmorillonite (NiSMM), cobalt-exchanged NiSMM, cobaltsubstituted mica montmorillonite, and nickel/uranium oxide catalysts were prepared and tested in a fixed-bed reactor for $\mathrm{NO}_{\mathrm{x}}$ reduction with methane in a $2 \%$ oxygen atmosphere over a range of temperatures from ambient to $550^{\circ} \mathrm{C}$. Reactions were performed in a Vicor tube reactor heated in a vertical furnace. Product gases were analyzed by direct interface of the column to an infrared 
spectrometer cell. Earlier tests that were carried out in a stainless steel reactor were determined to be influenced significantly by reactions occurring on the metal surface.

\subsection{Experimental}

\subsubsection{Catalysts}

The catalysts used in this study included the following:

Synthetic clays:

NiSMM (NiSMM was prepared by the method of Heinerman [15])

NiSMM + cobalt (NiSMM was impregnated with cobalt ions [16])

CoSMM (CoSMM was prepared by the method of Heinerman [15])

Oxide-supported metals:

Uranium oxide-nickel oxide (prepared by the method of Berry and coworkers [17])

\subsubsection{Equipment}

\subsubsection{FT-IR Spectrometer}

The Fourier transform infrared (FT-IR) spectrometer used is a Bomem Instruments MB-100 continuous scan Michelson interferometer, capable of determining wavenumbers with a precision of $0.01 \mathrm{~cm}^{-1}$. The instrument is fitted with a $10-\mathrm{cm}$ path length, heated gas cell and deuterated triglycine sulfate (DTGS) detector. The open-beam sensitivity (peak-to-peak SNR) of the instrument is 1400:1 for a 9-second observation time when equipped with the DTGS detector. All data from the instrument are collected using a 80486-based personal computer (PC) equipped with a digital signal processor board. Locally developed software is used to allow the instrument to collect and display data in real time. This facilitates the use of the instrument for process monitoring and control as well as conventional analytical applications. The PC and software are also capable of monitoring up to 21 analog channels while simultaneously acquiring IR data, allowing time synchronization of other measured parameters with the IR spectroscopic data.

The gas cell used has an optical path length of $10 \mathrm{~cm}$. The cell is equipped with $\mathrm{BaF}_{2}$ windows allowing a mid-IR passband of $800 \mathrm{~cm}^{-1}$ when used with the spectrophotometer described above. The gas cell is fabricated from stainless steel and has closed-loop temperature control. Its internal volume is approximately $50 \mathrm{cc}$.

\subsubsection{Gas-Mixing Equipment}

The input gas stream to the tube reactor was blended using four compressed gas cylinders, CP-grade methane, certified standard $4.99 \%$ nitric oxide in nitrogen, oxygen, and nitrogen. Gas cylinder flow for three of the cylinders was controlled using electronic mass flow controllers 
(MFCs). A calibrated floating ball-type meter and metering valve were used to set the nitrogen flow rate. The flow controllers and floating ball meter were calibrated for each gas using a primary flow standard. The linearity of MFC setpoint versus gas flow rate for each was checked using the primary flow standard and the gas for which the MFC was calibrated. The MFCs were used to control the flow of $\mathrm{NO}, \mathrm{CH}_{4}$, and $\mathrm{O}_{2}$, and the metering valve and floating ball-type meter were used for $\mathrm{N}_{2}$. The mass flow controllers and metering valve were set to give the gas composition specified for the experiment. The composition used for evaluation of the gas-mixing equipment was $2000 \mathrm{ppm} \mathrm{NO}, 2000 \mathrm{ppm} \mathrm{CH}_{4}, 2.5 \% \mathrm{O}_{2}$, and $97.2 \% \mathrm{~N}_{2}$. The repeatability of the gas mixture was verified by monitoring the output of the gas-mixing equipment with FT-IR.

\subsubsection{Procedure}

A 6" stainless steel or vicor glass tube reactor was packed with the desired catalyst $(+25$ mesh). The reactor was placed in a vertical furnace. The catalyst was activated by heating in a flow of hydrogen or nitrogen $(8-10 \mathrm{~mL} / \mathrm{min})$ at desired temperature $\left(350^{\circ}-400^{\circ} \mathrm{C}\right)$ for 2 hours. The tube reactor was attached to a gas supply through metering valves (see gas mixing above). The exit gases were passed through the FT-IR from the bottom of the reactor. The desired gas(es) was passed through the catalyst for desired length of time. After the desired reaction time, the flow of reactant gas(es) was stopped, but the flow of purge nitrogen was maintained for an additional period of 15 minutes to flush the products out of the reactor. A flow diagram for the reaction assembly is shown in Figure 1.

\subsection{Results}

\subsubsection{Selective Catalytic NO Reduction with Methane in Air}

Blank reactions were carried out in the Vicor tube inserted in the stainless steel reactor at $400^{\circ} \mathrm{C}$ with no catalyst present. The methane/nitrogen mixture was passed through the tube at $400^{\circ} \mathrm{C}$, and oxygen was then introduced. The reaction of methane with oxygen in the absence of NO resulted in the formation of a small amount of carbon dioxide and water, as expected for a nonselective noncatalytic oxidation of methane. In the blank (noncatalytic) reaction of NO with methane in the presence of oxygen, an equilibrium mixture of $\mathrm{NO}$ and $\mathrm{NO}_{2}$ formed, and no methane reacted with the $\mathrm{NO}_{\mathrm{x}}$.

In the catalytic reaction over a fixed bed of NiSMM, the addition of $\mathrm{O}_{2}$ to the methane in nitrogen stream gave carbon dioxide from combustion of the surface-bound carbon formed from the methane dissociation. When $\mathrm{NO}$ was added to the feed gas, $\mathrm{NO}_{2}$ appeared, and the $\mathrm{NO} / \mathrm{NO}_{2}$ mixture was obtained as in the noncatalytic blank run. The NO concentration was identical to the blank run, and the $\mathrm{NO}_{2}$ concentration was diminished by only $15 \%$. Very little of the methane reacted at $400^{\circ} \mathrm{C}$. Thus the synthetic clay-supported nickel was a poor catalyst for the reduction of $\mathrm{NO}_{\mathrm{x}}$ with methane in air. Similar negative results were obtained for the cobalt-exchanged NiSMM and the nickel/uranium oxide catalyst.

In the work reported by $\mathrm{Li}$ and Armor $(13,14), \mathrm{Co}, \mathrm{Mn}$, and Ni supported on ZSM-5 and mordenite were active for NO reduction with methane, but Y-zeolite was ineffective as the metal support. The results in both this and Li's report are consistent with the theory that traditional zeolite properties, such as high acidity and shape selectivity, are not important for this reaction, 


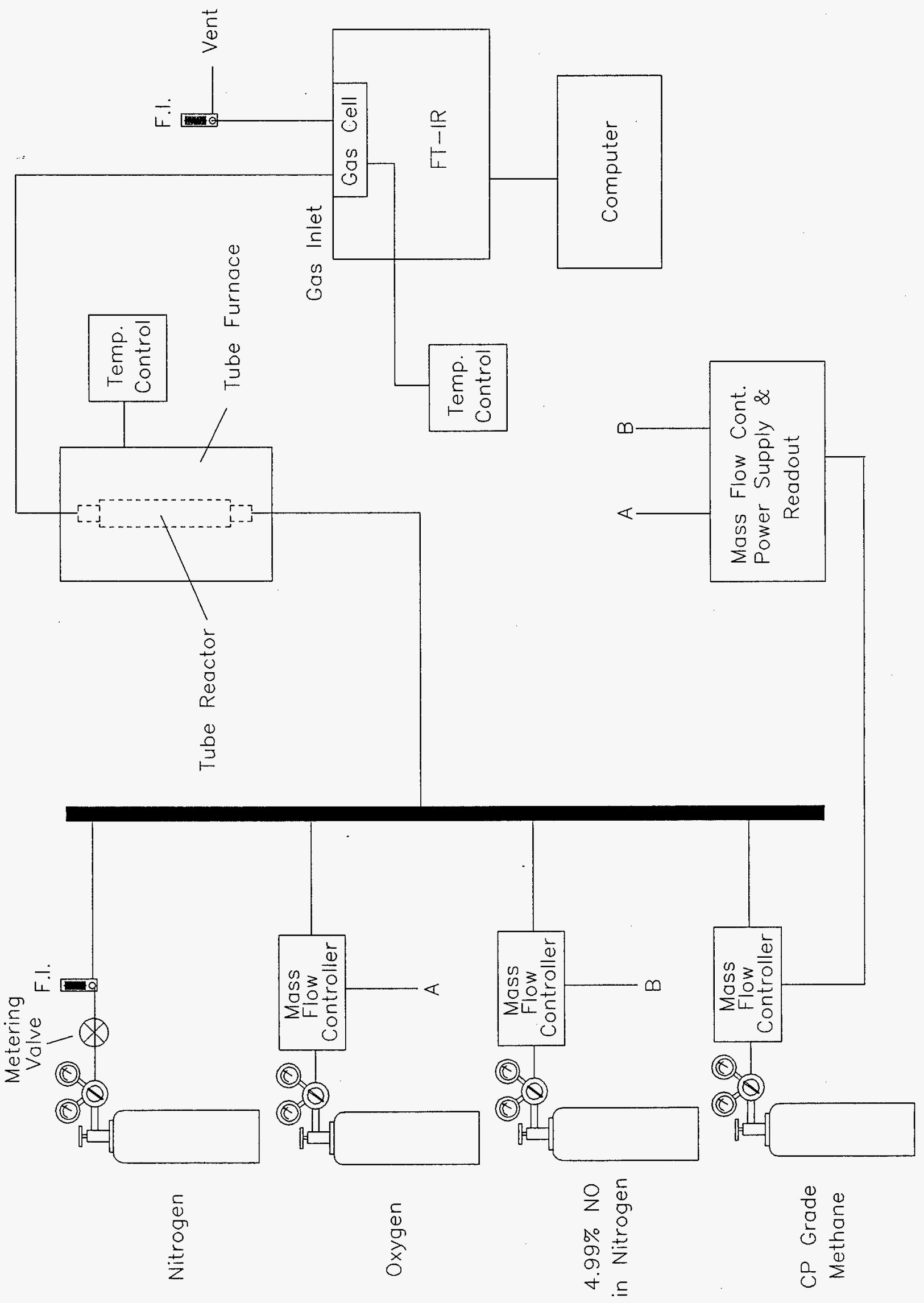


but some interaction between the metal cation and the support determines the reactivity of the catalyst. Thus the type of support is critical, and the synthetic clays and uranium oxide do not have the proper geometry for binding NO and catalyzing its reduction by methane.

\subsubsection{Catalytic Reduction of NO with Methane-Derived Intermediates}

The reaction of methane with the clay-supported nickel and cobalt was further investigated to determine if some chemistry could be utilized for $\mathrm{NO}_{\mathrm{x}}$ reduction under some conditions. The reaction of methane in nitrogen with the NiSMM at $450^{\circ} \mathrm{C}$ was performed in the absence of oxygen or $\mathrm{NO}(30 \mathrm{~min})$. The pretreated catalyst was then cooled rapidly to $150^{\circ} \mathrm{C}$, and the $\mathrm{NO} / \mathrm{N}_{2}$ was passed through the reactor. The NO concentration was lowered somewhat by the carbonaceous forms deposited on the catalyst, and $\mathrm{N}_{2} \mathrm{O}$ began to form along with some $\mathrm{CO}_{2}$. When oxygen was introduced at $150^{\circ} \mathrm{C}$, a small amount of $\mathrm{NO}_{2}$ appeared and the $\mathrm{N}_{2} \mathrm{O}$ decreased, but in this case only $15 \%$ of the $\mathrm{NO}_{2}$ concentration formed, compared with the earlier experiments.

Further examination of the details of methane reaction with the NiSMM showed that the methane was completely reacted with the catalyst bed at $450^{\circ} \mathrm{C}$. The second experiment also showed that no reduction of the NO occurred when introduced after cooling to $150^{\circ} \mathrm{C}$, and negligible amounts of $\mathrm{NO}_{2}$ were produced.

The Co-exchanged NiSMM was also heated with methane at $450^{\circ} \mathrm{C}$ for $30 \mathrm{~min}$. After cooling rapidly to $150^{\circ} \mathrm{C}$, the NO was added. Some initial reduction in the NO concentration was observed, but the concentration increased to the equilibrium level. Subsequent use of these methane-reduced catalysts at higher temperatures for NO reduction in air did not produce positive results.

Earlier work has examined the chemisorption of methane and the reactivity of the surfacebound carbon. Van Santen and coworkers (18) reported that $\mathrm{CH}_{4}$ is decomposed by a reduced Group VIII metal catalyst at $450-800 \mathrm{~K}$ into hydrogen and adsorbed surface carbonaceous species, which can be converted into hydrocarbons by hydrogenation with hydrogen at $300-400 \mathrm{~K}$ in a second step. Yang and coworkers (19) decomposed preabsorbed methane on a $\mathrm{Ni}(\mathrm{III})$ singlecrystal surface by a krypton bombardment at $47 \mathrm{~K}$ under ultrahigh vacuum condition $\left(\mathrm{P}=5 \times 10^{-6}\right.$ Torr). Tanaka and coworkers (20) created surface $\mathrm{CH}_{\mathrm{x}}$ fragments by dissociative methane adsorption around $700 \mathrm{~K}$ on a cobalt catalyst. None of these studies utilized NO as a substrate, however.

In order to determine the decomposition products of $\mathrm{CH}_{4}$ over $\mathrm{NiSMM}$ catalyst, $\mathrm{CH}_{4} / \mathrm{N}_{2}$ was passed over the NiSMM catalyst, which was prereduced by heating in a gentle flow of hydrogen at $450^{\circ} \mathrm{C}$ for 30 minutes. The effluent gas was analyzed by FT-IR. The data indicate almost quantitative decomposition of the $\mathrm{CH}_{4}$. The reactor was cooled to $150^{\circ} \mathrm{C}$, and a gentle flow of $\mathrm{H}_{2}$ was passed through the catalyst for several minutes. IR data for the effluent gas did not indicate the formation of hydrocarbons. It is thus possible that the carbonaceous material formed on the surface of the catalyst is not active for the hydrogen reaction, although it did have activity for $\mathrm{NO}_{2}$, as discussed above. van Santen reported that only the $\mathrm{C}$-alpha form of the surface-bound carbon is active for reaction with hydrogen. Upon aging $\mathrm{C}$-alpha was converted into $\mathrm{C}$-beta and $\mathrm{C}$-gamma, 
which are inactive carbon forms for hydrogenation. It is likely that these forms are present on the NiSMM surfaces, and they are only partly reactive with $\mathrm{NO}_{2}$.

\subsection{CONCLUSIONS}

The efficiency of the clay-supported nickel and cobalt catalysts for NO reduction with methane as the reducing gas is poor. The only catalysts that evidently can effect this reaction are those reported by $\mathrm{Li}$ and Armor $(13,14)$, who claim that only two zeolite-supported catalysts will activate methane for the NO reduction.

Results from the two-step experiments conducted at two temperatures are much more interesting. The carbonaceous material formed from methane dissociation at $450^{\circ} \mathrm{C}$ not only reduces $\mathrm{NO}$ to $\mathrm{N}_{2} \mathrm{O}$ at lower temperatures, but also prevents oxidation of $\mathrm{NO}$ to $\mathrm{NO}_{2}$. Unfortunately, the carbonaceous forms that reduce the $\mathrm{NO}$ are not available for reactions at $400^{\circ} \mathrm{C}$ in the presence of oxygen. A two-step process employing this chemistry would be difficult because the catalyst would have to be cycled between the two temperatures. Also the desired reduction to nitrogen is not very efficient.

\subsection{REFERENCES}

1. Sloss, L.L. $N O_{x}$ Emissions from Coal Combustion, IEA Coal Research: London, 1991.

2. Wood, S.C. Chem. Engineer. Prog. 1994, 32-38.

3. Hjalmarsson, A.-K. NO ${ }_{x}$ Control Technologies for Coal Combustion, IEA Coal Research: London, 1990.

4. Sato, S.; Hirabayashi, H.; Yahiro, H.; Mizuno, N.; Iwamoto, M. Catal. Lett. 1992, 12, 193-200.

5. Sato, S.; Yu-u, Y.; Yahiro, H.; Mizuno, N.; Iwamoto, M. Appl. Catal. 1991, 70, L1.

6. Iwamoto, M.; Yahiro, H.; Shundo, S.; Yu-u, Y.; Mizuno, N. Appl. Catal. 1991, 69, L15.

7. Misono, M.; Kondo, K. Chem.Lett. 1991, 1001-1002.

8. Yogo, K.; Tanaka, S.; Ihara, M.; Hishiki, T.; Kikuchi, E. Chem.Lett. 1992, 1025-1028.

9. Kikuchi, E.; Yogo, K.; Tanaka, S.; Abe, M. Chem. Lett. 1991, 1063-1066.

10. Hamada, H.; Kintaichi, Y.; Sasaki, M.; Ito, T.; Tabata, M. Appl. Catal. 1990, 64, L1-L4.

11. Hamada, H.; Kintaichi, Y.; Sasaki, M.; Ito, T.; Tabata, M. Appl. Catal. 1991, 70, L15-L20. 
12. Petunchi, J.O.; Sill, G.; Hall, W.K. Appl. Catal. B: Environ. 1993, 2, 303-321.

13. Li, Y.; Armor, J.N. Appl. Catal. B: Environ. 1993, 2, 239-256.

14. Li, Y.; Armor, J.N. Appl. Catal. B: Environ. 1992, 1, L31-L40.

15. Heinerman, J.J.L.; Freriks, I.L.C.; Graaf, J.; Pott, G.T.; Coglegem, J.G.F. J. of Catal. 1983, $80,145$.

16. Olson, E.S.; Sharma, R.K. Prepr. Pap.-Am. Chem. Soc., Div. Fuel Chem. 1994, 39 (3), 706.

17. Berry, F.J.; Murray, A.; Parkyns, N.D. Appl. Catal. A 1993, 100, 131.

18. Koerts, T.; Deelen, Marc J.G.A.G.; van Santen, R.A. Journal of Catalysis, 1992, 138, 101-114.

19. Yang, Q.Y.; Johnson, A.D.; Maynard, K.J.; Ceyer, S.T. J. Am. Chem. Soc. 1989, 111, 8748.

20. Tanaka, K.I.; Yaegashi, I.; Aomura, K. J. Chem. Soc. Chem. Commun. 1982, 938. 
M97005401

Minin

Report Number (14) DOE/MC/30097-- 5672

Jubl. Date (11) 199507

sponsor Code (18) DOE
sC Category (19)
LC $-101, D O E I E R$

DOE 